\title{
Medievalista
}

Online

$26 \mid 2019$

Número 26

\section{The triumphal cross of the cathedral of Nevers: painting technique and examination}

A cruz triunfal da Catedral de Nevers: técnica e exame de pintura

\section{Nadia Bertoni Cren and Stéphane Cren}

\section{(2) OpenEdition}

12 Journals

\section{Electronic version}

URL: http://journals.openedition.org/medievalista/2321

DOI: 10.4000/medievalista.2321

ISSN: 1646-740X

Publisher

Instituto de Estudos Medievais - FCSH-UNL

Printed version

Date of publication: 1 June 2019

\section{Electronic reference}

Nadia Bertoni Cren and Stéphane Cren, «The triumphal cross of the cathedral of Nevers: painting technique and examination », Medievalista [Online], 26 | 2019, Online since 27 July 2019, connection on 17 October 2019. URL : http://journals.openedition.org/medievalista/2321 ; DOI : 10.4000/ medievalista.2321 
Título / Title: The triumphal cross of the cathedral of Nevers: painting technique and examination / A cruz triunfal da Catedral de Nevers: técnica e exame de pintura Autor(es) / Author(s): Nadia Bertoni Cren (a); Stéphane Cren (b)

Afiliação institucional (Unidade de Investigação, Faculdade ou Departamento, Universidade, Código postal, Cidade, País) / Institutional Affiliation (Research Center, Faculty or Department, University, Postcode, City, Country): (a) Unité Mixte de Recherche 6298 ARTEHIS, Université de Bourgogne, 21000, Dijon, France;

(b) Restaurateur du patrimoine, 71390 , Chenôves, France

Email Institucional / Institutional email: nadia.bertoni@gmail.com /

info@crenconservation.fr

Fonte: Medievalista [Em linha]. Direc. Bernardo Vasconcelos e Sousa. Lisboa: IEM.

Disponível em:

http://www2.fcsh.unl.pt/iem/medievalista/MEDIEVALISTA26/cren-cren2607.html

ISSN: 1646-740X

DOI: 10.4000/medievalista.2321

Data de envio do artigo / Send for publication: 12 de novembro de 2018

Data aceitação do artigo / Accepted in revised form: 29 de abril de 2019 


\section{Abstract}

The large polychrome wooden cross preserved in the Saint-Cyr et Sainte-Julitte cathedral in Nevers was badly damaged during the bombing in July 1944. Restored and put on display on a modern cross in front of the choir, the sculpture suffered a new fall in 2015. The conservation of the work, directed by DRAC-CRMH of BurgundyFranche-Comté, was preceded by a phase of technical study. Micro-stratigraphic, taxonomic and radiometric analyses and the dendrochronology of the cross were carried out. The dendrochronology of the cross of Nevers and the comparison with radiocarbon dating place the elaboration of the work in the last quarter of the $12^{\text {th }}$ century while confirming the contemporaneousness of the cross with the sculpture. The quality of the triumphal cross of Nevers is highlighted even more by this dating which testifies to the richness of the formal contributions in Burgundy in the $12^{\text {th }}$ century.

Keywords: Wooden cross, Sculpture, Polychromy, Walnut, Azurite.

\section{Resumo}

A grande cruz de madeira policromada preservada na Catedral de Saint-Cyr et SainteJulitte em Nevers foi danificada com gravidade durante o bombardeamento de Julho de 1944. Restuarada e exposta numa cruz moderna em frente ao coro, a escultura sofreu uma nova queda em 2015. A conservação do trabalho, dirigida pelo DRAC-CRMH de Burdungy-Franche-Comté, foi precedida por uma fase de estudo técnico. Fizeram-se análises micro-estratigráficas, taxinómicas e radiométricas, bem como a dendrocronologia da cruz. A dendrocronologia da cruz de Nevers e a comparação com a datação por radiocarbono situaram a execução do trabalho no último quartel do século XII, confirmando que a. cruz e a escultura são contemporâneas. A qualidade da cruz triunfal de Nevers é ainda mais destacada com esta datação, que dá testemunho da riqueza dos contributos formais na Borgonha no século XII.

Palavras-chave: Cruz de madeira, Escultura, Policromia, Nogueira, Azurite. 


\title{
The triumphal cross of the cathedral of Nevers: Painting technique and examination / A cruz triunfal da Catedral de Nevers: técnica e exame de pintura
}

\author{
Nadia Bertoni Cren and Stéphane Cren
}

The large polychrome wooden cross preserved in the Saint-Cyr et Sainte-Julitte cathedral in Nevers consists of an oak support and a real-life walnut Christ. During the bombing in July 1944 that ravaged the cathedral, the triumphal cross was badly damaged. At the end of the rebuilding of the choir, the work was restored and put on display on a modern cross in front of the choir. The sculpture suffered a new fall in 2015. While falling, the right arm was detached from the body of the statue, many plaster fillings were detached and cracks appeared on the complexions of the thorax. The conservation of the work, directed by Arnaud Alexandre, curator of the Historical Monuments DRAC-CRMH of Burgundy-Franche-Comté, was preceded by a phase of technical study. Micro-stratigraphic, taxonomic and radiometric analyses and the dendrochronology of the cross were carried out. This allowed to collect new data and to specify the dating of the sculpture and the cross (fig. 1). 


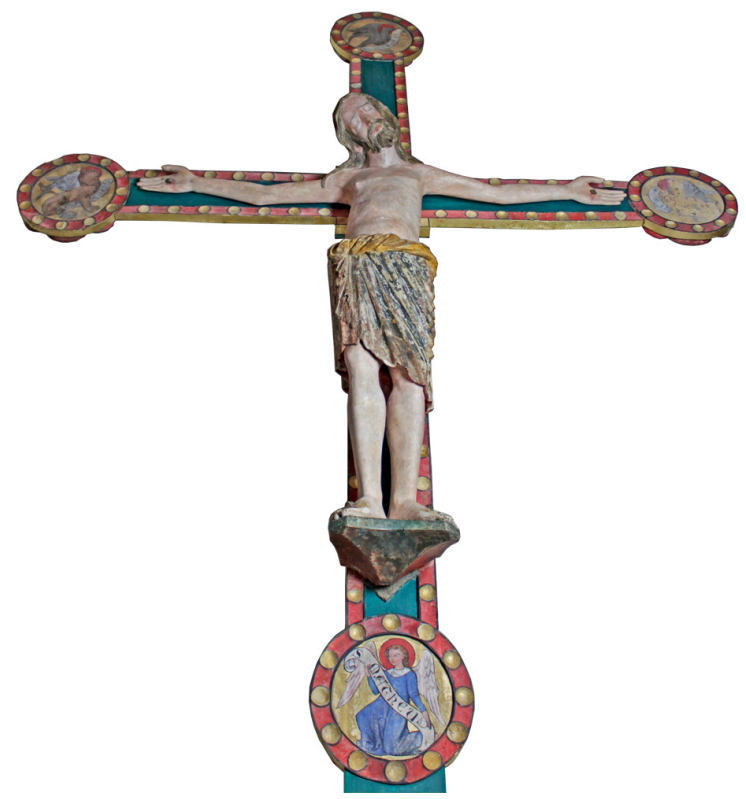

Fig. 1 - Triumphal cross, 1180-1200, polychromed wood: sculpture in walnut and cross in oak, $358 \times 272 \mathrm{~cm}$, Nevers cathedral, France

(C) Stéphane Cren).

\section{Description, style and comparisons}

The Christ is represented dead, head reclining on the right shoulder, eyes closed, without royal crown nor crown of thorns, according to the iconographic model of Christ patiens. However, the body is straight on the cross, standing on a suppedaneum. The feet, flat in external rotation, are attached separately and the arms are in horizontal position. These last iconographic elements generally define the sculptures of Christ from the $12^{\text {th }}$ century.

The loincloth is long, leaving the right knee uncovered, it descends slightly behind the calf on the left side. The rounded pleats and the belt formed by the wrapped around fabric are a stylistic sign of the 1200s. Paul Thoby inserted the sculpture in the first third of the $13^{\text {th }}$ century ${ }^{1}$, confirming the previous dating ${ }^{2}$. Since then, there have been no further studies of this remarkable work. A comparison with the stone heads from the

${ }^{1}$ THOBY, Paul - Le crucifix des origines au Concile de Trente. Étude iconographique. Nantes, 1959, pp.150-151, fig. 248-249.

${ }^{2}$ CROSNIER, Abbé Augustin Joseph - Monographie de la Cathédrale de Nevers. Société Nivernaise Des Lettres. Nevers, 1854, pp. 102-103. 
gallery of Kings of Notre-Dame de Paris preserved in the National Museum of the Middle Ages Thermes de Cluny, dated 1220, confirms this dating of the triumphal cross (fig. 2).

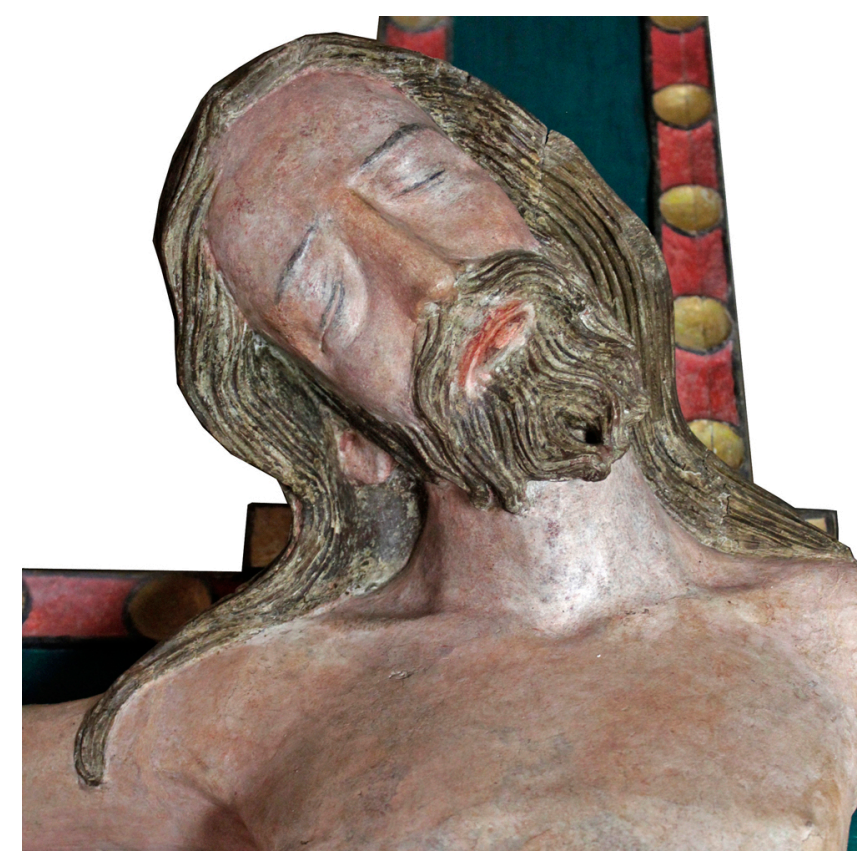

Fig. 2 - The Christ of the triumphal cross: detail of the face. 1180-1200, polychromed walnut, 187 x $187 \mathrm{~cm}$, Nevers cathedral, France

(C) Stéphane Cren).

Another stylistic reference for the head of Christ are two fragments of sculpture: the stone king's head from the portal of the west facade of the cathedral of Sens, dated 1190-1200, and the stone apostle's head still coming from the cathedral of Sens, preserved in the synodal hall, dated $1200^{3}$. The subtlety of the sculpture, the melancholy of the looks, the models of the faces inscribed in an oval, are representative of the classic movement of the years around 1200. The high quality of the sculpture in Nevers is reminiscent of an important workshop and an artist who normally carved the stone while working on the monumental decoration of cathedrals. In the current state of the studies, there does not seem to be another sculpture of Christ on a cross made out of cross polychrome wood datable around the year 1200 of Burgundy production.

\footnotetext{
${ }^{3}$ HOFFMANN, Konrad - The Year 1200. The Centennial exhibition at Metropolitan Museum of Art, the Cloisters. New York 1970, fig. 12-13, p. 10; SAUERLÄNDER, Willibald - Von Sens bis Strasburg. En beitrag zur kunstgeschichtlichen Stellung der Strasburger Querhausskulpturen. Berlin, 1966, fig. 110112.
} 
In northern Italy, the Christ of Gries (Bolzano) ${ }^{4}$, dated 1205 by an inscription, was associated by Walter Frodl and Theodor Müller with the sculptures of the north portal of Chartres. This work shows that the carved decoration of the great gates of the first Gothic art has influenced the sculpture of isolated in the round works not only in France.

The stylistic sources in Burgundy are culturally very diverse and the contemporary monumental sculpture has a decisive role. In the last quarter of the $12^{\text {th }}$ century, it was the art of stone carving of the great building sites of cathedrals that gave new forms to creative impulses. The harmonious naturalism of the forms and the poetic conception of the Christ of Nevers can only derive from the most innovative formulations experienced in monumental sculpture.

The cross is painted on both sides. On the front, the polychromy conforms to the iconographic type of the crux gemmata: along the edges, cavities simulate the location of the rock crystals or precious stones, the central part is painted in green, symbolizing the lignum vitae and at the ends the symbols of the evangelists are represented on four medallions. The back is carved in bas-relief with stylized flowers with blue and white quadrilobes surrounded by a red perimetral edge adorned with white leaves.

The Christ of Aschaffenburg 5 in Germany, from the end of the $10^{\text {th }}$ century, is the oldest wooden sculpture with a cross decorated on the edge with round motifs.

\footnotetext{
${ }^{4}$ RASMO, Nicolò - "Note sulla scultura medioevale atesina". Cultura Atesina, I, 1947, pp. 41-47; RASMO, Nicolò - "La scultura romanica nell'Alto Adige. Note e revisioni". Cultura Atesina, VII, 1953, pp. 9-47; FRODL, Walter - Kunst in Südtirol. München, 1960, p. 49; MÜLLER, Theodor - "Ein romanicher Crocifixus aus Tirol". Pantheon, LIV, 1974, pp.13-17; MÜLLER, Theodor - Gotische Skulptur in Tirol. Bozen-Innsbruck-Wien, 1976, p. 11, fig. 1; SPADA PINTARELLI, Silvia - "Anonimo scultore 1205. Crocifisso, Bolzano vecchia parrocchiale di Gries". in CASTELNUOVO, Enrico (ed.), Imago Lignea. Sculture lignee nel Trentino dal XIII al XVI secolo. Trento, 1989, pp. 86-87; CERVINI, Fulvio - "Di alcuni crocifissi trionfali del secolo XII nell'Italia Settentrionale". Arte Medievale, VII, 2008, 1, p. 24; MOR, Luca - "Anno 1205 circa: la Croce trionfale di Gries". in CANTONE, Valentina, FUMIAN, Silvia (ed.) - Le Arti a confronto con il Sacro. Metodi di ricerca e nuove prospettive d'indagine in ottica interdisciplinare. Padova, 2009, pp. 71-79.

${ }^{5}$ BEER, Manuela - Triumphkreuze des Mittelalters. Ein Beitrag zu Typus und Genese im 12. Und 13. Jahrhundert. Ratisbone, 2005; PAWLIK, Anna - "Mathildes Gedächtnisstiftung in Aschaffenburg". in FALK, Birgitta; HÜLSEN-ESCH, Andrea von (ed.) - Mathilde, Glanzzeit des Essener Frauenstifts. Essen, 2011, pp. 144-147.
} 
Another important example of this form of cross, with its sculpture of Christ dated 1180-1200, is situated in Belgium in the church of Saint-Denis in Forest (Brussels) ${ }^{6}$. The cross potent has large flowers with quatrefoils at the ends and concave circles according to the same ornamental concept as the one of the cross of Nevers. On this cross the original layer and the first overpaint have the centre painted in green and the edges painted in red with golden concave parts.

Crosses similar to that of Nevers, surrounded by concave circles on the edges and with ends enlarged by the application of the symbols of the four evangelists, are preserved in several churches on the island of Gotland in Sweden. These are the crosses of thirteenthcentury-Christ carvings of churches from Lokrume ${ }^{7}$ and from Gerum, with a complete overpaint that seems to date from the Baroque era, from Hejdeby ${ }^{8}$, from Grotlingbo ${ }^{9}$, from Fole ${ }^{10}$, with the fabric of the loincloth wrapped around a belt, and from Fide, with the symbols of the evangelists on the four ends of the cross.

On a cross from the $12^{\text {th }}$ century, belonging to the group of the crucifixion of Urnes ${ }^{11}$ in Norway, a modification of the ends of the cross, with gilded circles bearing the symbols of the evangelists, can be referred to the $13^{\text {th }}$ century as the second polychrome phase of the whole. In North Jutland, the cross of the church of Vrensted ${ }^{12}$, dated 1200, is also a testimony of the spreading in Northern Europe of these forms of cross that could be completed by a large circle with painted medallions, surrounding the upper part of the body of Christ. The development of new iconographic formulas is not easy to detect but in Scandinavia an influence of Rhenish plastic arts as well as a French one is attested for the $12^{\text {th }}$ and $13^{\text {th }}$ centuries.

\footnotetext{
${ }^{6}$ BALleStrEM, Agnes; PUISSANT, Martine - "La croix triomphale de l'église de Saint-Denis à Forest. Essai d'identification, examen et traitement”. Bulletin IRPA, XIII. Bruxelles, 1971/72, pp. 52-77.

${ }^{7}$ UGGLAS, Carl R. - Gotlands medeltida träskulptur till och med höggotikens inbrott. Stockholm, 1915, p. 303 , fig. 76 .

${ }^{8}$ UGGLAS, Carl R. - Gotlands medeltida träskulptur..., p. 301, fig. 74.

${ }^{9}$ UGGLAS, Carl R. - Gotlands medeltida träskulptur..., p. 285, fig. 63.

${ }^{10}$ UGGLAS, Carl R. - Gotlands medeltida träskulptur..., p. 286, fig. 64.

${ }^{11}$ FRØYSAKER, Tine; KOLLANDSRUD, Kaja - "The Calvary group in Urnes Stave church, Norway: a technological examination". in NADOLNY, Jilleen (ed.) - Medieval Painting in Northern Europe. Techniques, analysis, art history. London, 2006, pp. 59-75.

12 NYBORG, Ebbe - "Danish Panel Painting until c. 1300". in NADOLNY, Jilleen (ed.) - Medieval Painting in Northern Europe... cit. pp. 248-265, fig. 4.
} 


\section{Material study}

Dimensions: the sculpture of Christ is 187 high, $176 \mathrm{~cm}$ without suppedaneum, and 187 $\mathrm{cm}$ wide. The dexter arm measures $78 \mathrm{~cm}$. The maximum width without the arms is 35 $\mathrm{cm}$ and the depth is $32 \mathrm{~cm}$. The cross is $358 \mathrm{~cm}$ high and $272 \mathrm{~cm}$ wide. The maximum thickness is $7.5 \mathrm{~cm}$. The three medallions have a diameter of $43 \mathrm{~cm}$ and a thickness of $7.5 \mathrm{~cm}$.

The body and the dexter arm are made of walnut (Juglans regia L.) ${ }^{13}$. The body is carved in a log about $50 \mathrm{~cm}$ in diameter. The marrow is at the centre of the log with an inclined axis, one end of which is observable behind the head. On the backhand side a long fairly regular cavity $(\mathrm{H} \mathrm{71,} \mathrm{W} \mathrm{10,} \mathrm{D} 17.5 \mathrm{~cm})$ was dug from the shoulders up to two thirds of the loincloth with rounded gouges of different sizes. At the level of the loincloth, the statue is $35 \mathrm{~cm}$ wide and the sapwood of the peripheral areas has not been purified.

The two arms were carved separately and inserted with tenon and mortise joints blocked by an oak peg fixed under the armpit to be less visible. The mortise cut in the dexter shoulder measures approximately $4 \times 4 \mathrm{~cm}$ and is $4.5 \mathrm{~cm}$ deep. The arm and a part of the sinister shoulder as well as the last phalanges of the three fingers and the little finger and a part of the palm of the dexter hand were rebuilt during the restoration of 1964 . On the dexter part of the belly, a trapezoidal graft held by a peg $2.3 \mathrm{~cm}$ in diameter can be observed. On the feet, toes were grafted and the heel of the dexter foot was reworked.

Five old perforations $2.3 \mathrm{~cm}$ in diameter are present at the back of the statue: two on the shoulders, one on the bottom of the loincloth and two on the suppedaneum. They correspond to holes of the same diameter on the cross which allowed to fix the statue with pegs. The cross is made of many elements in oak wood (Quercus sp.). The vertical and the horizontal branches are placed in interlocking cross-beams. Three medallions are added to the cross at the upper end of the vertical branch and at the ends of the horizontal branch. They are each fixed by two wooden dowels of about $2.5 \mathrm{~cm}$. During

\footnotetext{
${ }^{13}$ PRINCIVALLE, Alessandro - Christ en croix en bois polychrome et ancienne croix de la cathédrale de
} Nevers. Rapport des analyses préalables à la restauration. Montagnana, 2017. 
the last restoration, the medallions were secured with screwed metal flat spots. The three medallions are made of two discs glued against each other. Each disc is made of two juxtaposed pieces.

The dendrochronology of the cross of Nevers ${ }^{14}$, thanks to the ring dated 1122, anticipates the creation of the triumphal cross by locating it after 1150. This new data and the comparison with radiocarbon dating ${ }^{15}$ place the elaboration of the work in the last quarter of the $12^{\text {th }}$ century, or around the year 1200 , while confirming the contemporaneousness of the cross with the sculpture.

The pictorial layer of the cross can be referred to the neo-Gothic taste of the $19^{\text {th }}$ century and largely goes back to the restoration that followed the rediscovery of the work in 1868. During the intervention carried out in 1964 by Maxime Chiquet, the original polychromy of the loincloth was skimpily cleared leaving remnants of different overpaints and deficiencies with the visible support wood. The cross has also been restored with illusionist inpainting. The observation in the polychromy deficiencies and the tests done as well as the laboratory analyses carried out by Alessandro Princivalle ${ }^{16}$, allowed to document four polychrome phases.

The preparation of the original polychromy consists of calcium carbonate and of drying oil. The complexions are made of an oily undercoat from calcium carbonate and lead white and then a layer of lead white, with little calcium carbonate, pigmented with vermilion. The entire build-up layer is bound by drying oil, which traces are found on the surface as protection.

The loincloth was blue with red lapels and gilded decorations in the shape of flowers and half-moons. The lower part was adorned with a golden edge heightened with red

\footnotetext{
${ }^{14}$ FRAITURE, Pascale - Rapport de dendrochronologie, Nevers, Cathédrale Saint-Cyr-et-Sainte-Julitte, Croix d'un Christ en croix. IRPA, Bruxelles, 2017.

${ }^{15}$ BOUDIN, Mathieu - Radiocarbon dating report, Cathédrale de Nervers, Croix du Christ, Statue du Christ. IRPA, Bruxelles, 2017.

${ }^{16}$ PRINCIVALLE, Alessandro - Christ en croix en bois polychrome.... Microstratigraphic analyses were carried out on five layer samples via thin-layer optical microscopy of stratigraphic section, scanning electron microscopy (SEM) with elemental analysis via energy dispersive X-ray spectrometry (EDS) for the characterization of the inorganic components, and Fourier transform infrared spectroscopy (FTIR) for the characterization of the organic substances.
} 
and green glazes forming red crosses. Blue was obtained by laying a bluish-black undercoat made of lead white, little calcium carbonate and little bone black. The gilded decorations were made by placing a mixture of calcium carbonate, white lead and redorange ochre. The gold leaf contains traces of silver. The blue pictorial layer is given by blue azurite mixed with lead white. The whole build-up layer is characterized by the presence of drying oil. The gilded adornments are placed on the black-bluish undercoat and before being rounded with azurite (fig. 3, fig. 4). The suppedaneum was green and red with gilded decorations. The green central part was obtained by applying verdigris mixed with lead white. This oily layer is covered by a double layer of brownish oily protection.

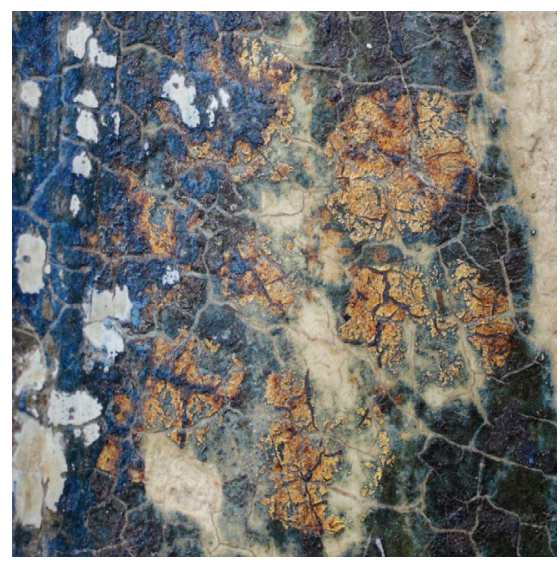

Fig. 3 - The Christ of the triumphal cross: detail of a gilded decoration in the shape of a flower on the loincloth. 1180-1200, polychromed walnut, Nevers cathedral, France

(C) Stéphane Cren).

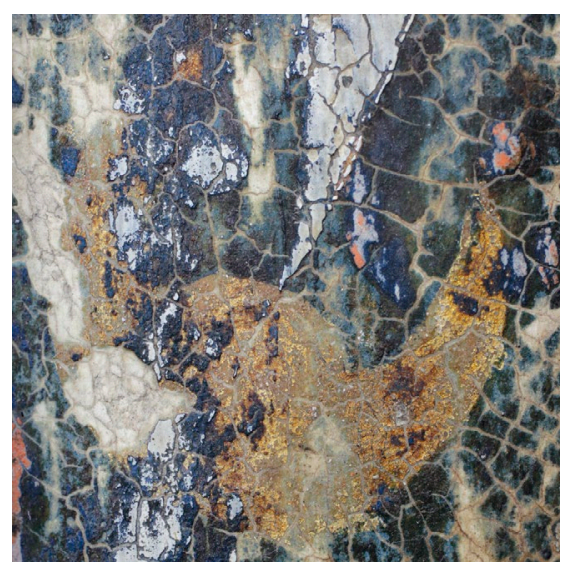

Fig. 4 - The Christ of the triumphal cross: detail of a gilded decoration in the shape of a halfmoon on the loincloth. 1180-1200, polychromed wood, Nevers cathedral France (C) Stéphane Cren). 
The blue azurite (blue copper carbonate) is documented for the second time on a wood carving of the Burgundian Romanesque corpus. It has been noticed on the Christ of Abbadia San Salvatore ${ }^{17}$, sculpture of the first half of the $12^{\text {th }}$ century found in Tuscany. This pigment, more often used in the $14^{\text {th }}$ century, has been identified in small quantity in the lapis lazuli blue on the Christ de Forest (Belgium) dated from the late $12^{\text {th }}$ century.

The use of bone black has to been mentioned. This pigment, like ivory black, was obtained since ancient times by burning bones. The pigment is lightfast with medium coverage and a darker and warmer hue compared to vegetable blacks such as carbon black or vine black. At the current state of analysis of the sculptures of the $11^{\text {th }}-12^{\text {th }}$ century, carbon black of vegetable origin is prevailing ${ }^{18}$.

A half-moon with flowers motif similar to the adornment of the loincloth of the Christ of Nevers is present on the loincloth of the Swedish Christ of Linde (Gotland) of the Historiska museet in Stockholm dated $1200^{19}$. The original painting technique of the Christ on the cross, mainly in oil, is not an isolated case for polychrome sculpture of the $12^{\text {th }}$ century. Peter Tångeberg ${ }^{20}$ had already pointed this out in his study of the Christ of Hemse (1170-1190), where parallels were made with the Virgin of Viklau dated 1170 (Statens Historiska museet Stockholm, inv. 18951), the Christ of Cappemberg (12001220) and the Angel sitting on the throne in Berlin-Dahlem (Staatliche Museen), probably coming from Cologne, dated about 1170. All these works have a well-

\footnotetext{
${ }^{17}$ BERTONI CREN, Nadia; CREN, Stéphane - "Note dal restauro del crocefisso di San Salvatore". in PREZZOLINI, Carlo (ed.) - Il crocifisso di Abbadia San Salvatore. Catechesi e Arte. Montepulciano (Siena), 2010, pp. 33-41.

${ }^{18}$ SERK DEWAIDE, Myriam; VERFAILLE, Simone - Le vieux Bon Dieu de Tancrémont. Bruxelles, 1987; SERCK DEWAIDE, Myriam; KOCKAERT, Leopold; VAN STRYDONCK, Marc; VERFAILLE, Simone - "Le vieux Bon Dieu de Tancrémont. Histoire et traitement". Bulletin de l'IRPA, XXIII. Bruxelles, 1991, pp. 80-100; SERK DEWAIDE, Myriam - "Notre-Dame de Walcourt, une Vierge ottonienne et son revers du XIII ${ }^{\circ}$ siècle. La statue en bois polychromé'. Bulletin de l'IRPA, 25, 1993/94 (1996), pp. 45-47. See the pigments of the Christ of Tancremont, the Notre Dame of Walcourt, the Christ of Forest and the Christ of Abbadia San Salvatore.

${ }^{19}$ UGGLAS, Carl R. - Gotlands medeltida träskulptur..., pp. 307-308, fig. 81; TÅNGEBERG, Peter Holzskulptur und Altarschrein. Studien zu Form, Material und Technik. München, 1989, fig. 83, p.123. Inv. $\mathrm{nr} 8084: 1, \mathrm{H} 87.5 \mathrm{~cm}$. A copy of the sculpture is in the church of Linde, made in 1930 by Anton Hällström, Stockholm. This sculpture has the particularity of having black shoes adorned with gold leaf buckles. Christs with shoes are rare; also see the Christ of Stenkumla, $12^{\text {th }}$ century, in Gotland.

${ }^{20}$ TÅNGEBERG, Peter - "The Crucifix from Hemse". Maltechnik Restauro, 1. München, 1984, pp. 2433; PLAHTER, Unn - "The Crucifix from Hemse. Analyses of the Painting Technique". Maltechnik Restauro, 1. München, 1984, pp. 35-44.
} 
preserved polychromy characterized by an oil binder. In his essay, Tångeberg had moreover noticed that at the same time Scandinavian works in polychrome wood made with an oily technique coexisted with works marked by a system of pigments with various binders (oil, glue, egg, resin, or oil + glue). On the wooden sculptures of the Burgundian corpus of the Romanesque period which has been analysed until now, the same paradigm seems to emerge.

\section{Conclusion}

The quality of the triumphal cross of Nevers is highlighted even more by the dendrochronological and radiocarbon datings which testify to the richness of the formal contributions in Burgundy in the $12^{\text {th }}$ century.

The classical forms of the folds of the loincloth, the naturalism of the anatomy and the face depend on the sculpture sites of the great cathedrals of the second half of the $12^{\text {th }}$ century. These innovations coexist with a figure of Christ in an attitude that follows the principles of his representation applied since the $10^{\text {th }}$ century. The triumphal cross of Nevers takes up the iconography of the crux gemmata which is widespread in northern Europe. The example of small goldsmith's crosses adorned with precious stones and enamels is transferred in large dimensions through the polychrome wood.

The technique of the carving of the sculpture is an early example of the practices that are commonly observed in the $13^{\text {th }}$ and $14^{\text {th }}$ centuries. The back cavity is deep and carved freely with the help of a gouge and no longer with a doloire or an adze. Polychromy, meanwhile, is characterized by the use of bone black and azurite blue with a drying oil as a binder. This pigment will be more used in the following centuries with, however, an aqueous binder which gives a lighter hue ${ }^{21}$.

\footnotetext{
21 The complete article is published in French in the Bulletin de la Société Nivernaise des Lettres,
} Sciences et Arts de Nevers, année 2019. Translation by David Poingt. 


\section{BIBLIOGRAPHICAL REFERENCES:}

\section{Printed sources}

BALLESTREM, Agnes; PUISSANT, Martine - "La croix triomphale de l'église de Saint-Denis à Forest. Essai d'identification, examen et traitement". Bulletin IRPA, XIII. Bruxelles, 1971/72.

BEER, Manuela - Triumphkreuze des Mittelalters. Ein Beitrag zu Typus und Genese im 12. Und 13. Jahrhundert. Ratisbone, 2005.

BERTONI CREN, Nadia; CREN, Stéphane - "Note dal restauro del crocefisso di San Salvatore". in PREZZOLINI, Carlo (ed.) - Il crocifisso di Abbadia San Salvatore. Catechesi e Arte. Montepulciano (Siena), 2010.

CERVINI, Fulvio - "Di alcuni crocifissi trionfali del secolo XII nell'Italia Settentrionale". Arte Medievale, VII, 2008, 1.

CROSNIER, Abbé Augustin Joseph - Monographie de la Cathédrale de Nevers. Société Nivernaise Des Lettres. Nevers, 1854.

FRODL, Walter - Kunst in Südtirol. München, 1960.

FALK, Birgitta; HÜLSEN-ESCH, Andrea von (ed.) - Mathilde, Glanzzeit des Essener Frauenstifts. Essen, 2011.

FRØYSAKER, Tine; KOLLANDSRUD, Kaja - "The Calvary group in Urnes Stave church, Norway: a technological examination”. in NADOLNY, Jilleen (ed.) - Medieval Painting in Northern Europe. Techniques, analysis, art history. London, 2006.

HOFFMANN, Konrad (ed.) - The Year 1200. The Centennial exhibition at Metropolitan Museum of Art, the Cloisters. New York, 1970. 
MOR, Luca - “Anno 1205 circa: la Croce trionfale di Gries". in CANTONE, Valentina; FUMIAN, Silvia (ed.) - Le Arti a confronto con il Sacro. Metodi di ricerca e nuove prospettive d'indagine in ottica interdisciplinare. Padova, 2009.

MÜLLER, Theodor - “Ein romanicher Crocifixus aus Tirol”. Pantheon, LIV, 1974.

MÜLLER, Theodor - Gotische Skulptur in Tirol. Bozen-Innsbruck-Wien, 1976.

NADOLNY, Jilleen (ed.) - Medieval Painting in Northern Europe. Techniques, analysis, art history. London, 2006.

NYBORG, Ebbe - "Danish Panel Painting until c. 1300”. in NADOLNY Jilleen (ed.) Medieval Painting in Northern Europe. Techniques, analysis, art history. London, 2006.

PAWLIK, Anna - "Mathildes Gedächtnisstiftung in Aschaffenburg". in FALK, Birgitta; HÜLSEN-ESCH, Andrea von (ed.) - Mathilde, Glanzzeit des Essener Frauenstifts. Essen, 2011.

PLAHTER, Unn - "The Crucifix from Hemse. Analyses of the Painting Technique". Maltechnik Restauro, 1. München, 1984.

RASMO, Nicolò - "Note sulla scultura medioevale atesina", Cultura Atesina, I, 1947.

RASMO, Nicolò - "La scultura romanica nell'Alto Adige. Note e revisioni”, Cultura Atesina, VII, 1953.

SAUERLÄNDER, Willibald - Von Sens bis Strasburg. En beitrag zur kunstgeschichtlichen Stellung der Strasburger Querhausskulpturen. Berlin, 1966.

SERK DEWAIDE, Myriam; VERFAILLE, Simone - Le vieux Bon Dieu de Tancrémont. Bruxelles, 1987. 
SERCK DEWAIDE, Myriam M.; KOCKAERT, Leopold; VAN STRYDONCK, Marc;

VERFAILLE, Simone - "Le vieux Bon Dieu de Tancrémont. Histoire et traitement". Bulletin de l'IRPA, XXIII. Bruxelles. 1991.

SERK DEWAIDE, Myriam - "Notre-Dame de Walcourt, une Vierge ottonienne et son revers du XIII ${ }^{\circ}$ siècle. La statue en bois polychrome”. Bulletin de l'IRPA, 25. Bruxelles, 1993/94 (1996).

SPADA PINTARELLI, Silvia - “Anonimo scultore 1205. Crocifisso, Bolzano vecchia parrocchiale di Gries”. in CASTELNUOVO, Enrico (ed.), Imago Lignea. Sculture lignee nel Trentino dal XIII al XVI secolo. Trento, 1989.

TÅNGEBERG, Peter - Holzskulptur und Altarschrein. Studien zu Form, Material und Technik. München, 1989.

TÅNGEBERG, Peter - “The Crucifix from Hemse”. Maltechnik Restauro 1, München, 1984.

THOBY, Paul - Le crucifix des origines au Concile de Trente. Étude iconographique. Nantes, 1959.

UGGLAS, Carl R. - Gotlands medeltida träskulptur till och med höggotikens inbrott. Stockholm, 1915.

\section{Studies}

PRINCIVALLE, Alessandro - Christ en croix en bois polychrome et ancienne croix de la cathédrale de Nevers. Rapport des analyses préalables à la restauration. Montagnana, 2017.

FRAITURE, Pascale - Rapport de dendrochronologie, Nevers, Cathédrale Saint-Cyret-Sainte-Julitte, Croix d'un Christ en croix. IRPA, Bruxelles, 2017.

BOUDIN, Mathieu - Radiocarbon dating report, Cathédrale de Nervers, Croix du Christ, Statue du Christ. IRPA, Bruxelles, 2017. 


\section{COMO CITAR ESTE ARTIGO}

\section{Referência electrónica:}

BERTONI CREN, Nadia; CREN, Stéphane - "The triumphal cross of the cathedral of Nevers: painting technique and examination". Medievalista 26 (Julho-Dezembro 2019). [Em linha] [Consultado dd.mm.aaaa]. Disponível em http://www2.fcsh.unl.pt/iem/medievalista/MEDIEVALISTA26/cren-cren2607.html ISSN 1646-740X.

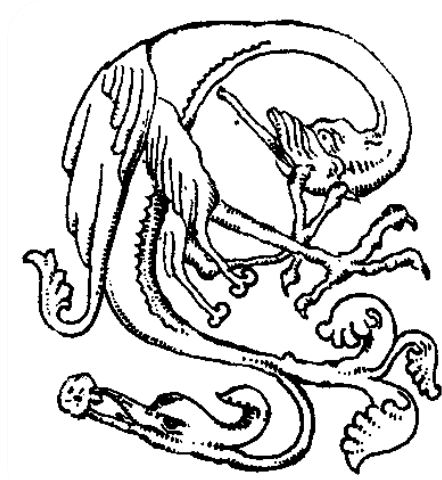

